\title{
PIGEON PEA YIELDS AS INFLUENCED BY PLANTING DATE AND PRUNING ${ }^{1,2}$
}

\author{
Edmundo Rivera and Héber Irizarry ${ }^{3}$
}

\begin{abstract}
This research determined the effect of planting date and pruning on the productivity of five pigeon pea cultivars planted under humid tropical conditions at Corozal and under wet-dry tropical conditions at Santa Isabel (under irrigation). With proper management, two successful heavy crops of pigeon peas were obtained from December to May from plots planted March, June and September, with average total yield of $10,800 \mathrm{~kg}$ of mature pods/ha. At Corozal, highest yields were obtained from the September planting with the 2B-Bushy cultivar, $12,900 \mathrm{~kg}$ of mature-green pods/ha. At Santa Isabel, with irrigation, pigeon peas yielded about $25 \%$ more than at Corozal, and determinate line 147 produced the highest yields, $16,195 \mathrm{~kg}$ of mature-green pods/ ha. Pruning the pigeon pea bushes after harvesting the first crop decreased yields of the following crop at both locations, at all planting dates and in all cultivars.
\end{abstract}

\section{INTRODUCTION}

Pigeon pea (Cajanus cajan (L.) Millsp.) is a bushy tropical legume that can do well on relatively infertile soil and can tolerate periodic droughts, probably because of its well developed deep root system. Rivera et al. (6) found that roots of 5-month-old pigeon peas growing in an Ultisol reached a depth of $150 \mathrm{~cm}$ with $400 \mathrm{~cm}$ of roots per liter of soil. Irizarry and Rivera (3) found that intensively managed high yielding pigeon peas $(8,000 \mathrm{~kg}$ of mature green pods/ha) took up 216,12, 168, 54 and $19 \mathrm{~kg} /$ ha of $\mathrm{N}, \mathrm{P}, \mathrm{K}, \mathrm{Ca}$ and $\mathrm{Mg}$, respectively.

Because pigeon peas are sensitive to photoperiod, planting date can markedly affect yields. In Puerto Rico, Riollano et al. (5) and Abrams and Juliá (1) working with indeterminant cultivars at Isabela found that yields from early plantings (April-June) were higher than those obtained from plantings made later in the year. No attempt has been made to study the effect of pruning on yields of pigeon pea. However, in studies with pigeon peas as a source of forage, Olivencia (4) and Soldevila and Salas-Herrero (7) reported a strong regrowth by 7 -month old 2-B-Bushy cultivar after being cut back to a height of $15 \mathrm{~cm}$.

The present study was designed to determine the effect of planting dates and pruning on yields of five pigeon pea cultivars in two ecological regions.

${ }^{1}$ Manuscript submitted to Editorial Board April 18, 1983.

${ }^{2}$ This paper covers work carried out cooperatively between the Agricultural Research Service, USDA and the College of Agricultural Sciences, Mayagüez Campus, University of Puerto Rico.

${ }^{3}$ Horticulturists, Agricultural Research Service, USDA. 


\section{MATERIALS AND METHODS}

The experiments were conducted at the Corozal Substation in the humid mountain region near Santa Isabel on the semi-arid south coast, under irrigation.

The Corozal Substation is located about $200 \mathrm{~m}$ above sea level. Average annual rainfall is about $1,700 \mathrm{~mm}$ with mean minimum and maximum monthly temperatures of 19.8 and $30.1^{\circ} \mathrm{C}$, respectively. The soil is Corozal clay (Aquic Tropudults) with an initial $\mathrm{pH}$ of 4.9 . About $4.5 \mathrm{t} /$ ha of ground limestone were applied to raise soil $\mathrm{pH}$ to 5.3. The soil contained $5 \mathrm{p} / \mathrm{m}$ of "available" $\mathrm{P}$ (Bray method) and 0.5, 8.5 and 2.9 meq/100 g of soil of exchangeable $\mathrm{K}, \mathrm{Ca}$, and $\mathrm{Mg}$, respectively.

At Santa Isabel, rainfall is about $1,000 \mathrm{~mm}$ yearly with a well defined dry season. Average minimum and maximum monthly temperatures are 21.3 and $31.0^{\circ} \mathrm{C}$, respectively. The soil is San Antón sandy clay (Cumulic Haplustolls) with a $\mathrm{pH}$ of 7.5 , containing $28 \mathrm{p} / \mathrm{m}$ of "available" P (Bray method) and $0.8,19.3$ and $9.3 \mathrm{meq} / 100 \mathrm{~g}$ of soil of exchangeable $\mathrm{K}, \mathrm{Ca}$, and $\mathrm{Mg}$, respectively.

The soil was plowed and harrowed. Seeds were planted $30 \mathrm{~cm}$ apart in rows $90 \mathrm{~cm}$ apart (37,000 plants/ha). Plots were $7 \times 4 \mathrm{~m}$ surrounded by border rows and replicated six times in complete blocks.

All plots received $450 \mathrm{~kg}$ of a $10-10-10$ fertilizer/ha 2 weeks after planting and again about 3 months later. At Santa Isabel, furrow irrigation was applied at the rate of $75 \mathrm{~mm}$ every 3 weeks. Insects were controlled by following recommendations of the Agricultural Experiment Station (2). All experiments were hand-weeded as necessary.

Five pigeon pea cultivars, 2-B-Bushy (determinate), Kaki (indeterminate), and lines 98,147 and 148 (determinate types developed by the Agricultural Experiment Station) were sown in mid-September and December, 1980, and in mid-March and June, 1981 at the Corozal Substation and in mid-September 1980 at Santa Isabel. As a subtreatment we tested the effect of pruning plants to a height of $60 \mathrm{~cm}$ after the first crop was harvested.

In another experiment with line 147 planted in July 1980 at the Corozal Substation, four pruning levels were evaluated: no pruning, trimming about $8 \mathrm{~cm}$ from branch tips, pruning the plants to a height of $30 \mathrm{~cm}$ or to a height of $60 \mathrm{~cm}$.

All experiments were harvested by hand as the pods matured, and yields are expressed in $\mathrm{kg}$ of mature-green pods/ha.

At present, most commercial farmers plant pigeon peas in the fall and harvest only one crop. In Santa Isabel, with irrigation, average yields on farms using current practices are about $2,000 \mathrm{~kg} / \mathrm{ha}$ whereas farms who follow improved practices average $4,500 \mathrm{~kg} / \mathrm{ha}$. 


\section{RESULTS AND DISCUSSION}

\section{COMPARISON OF CULTIVARS}

At the Corozal Substation, highest and lowest yields for all determinate cultivars were obtained from the September and December plantings, respectively (fig. 1). In the September planting the 2-B-Bushy and lines 147 and 148 were the highest yielders, averaging $12,090 \mathrm{~kg}$ of maturegreen pods/ha (table 1). The indeterminate Kaki cultivar produced the

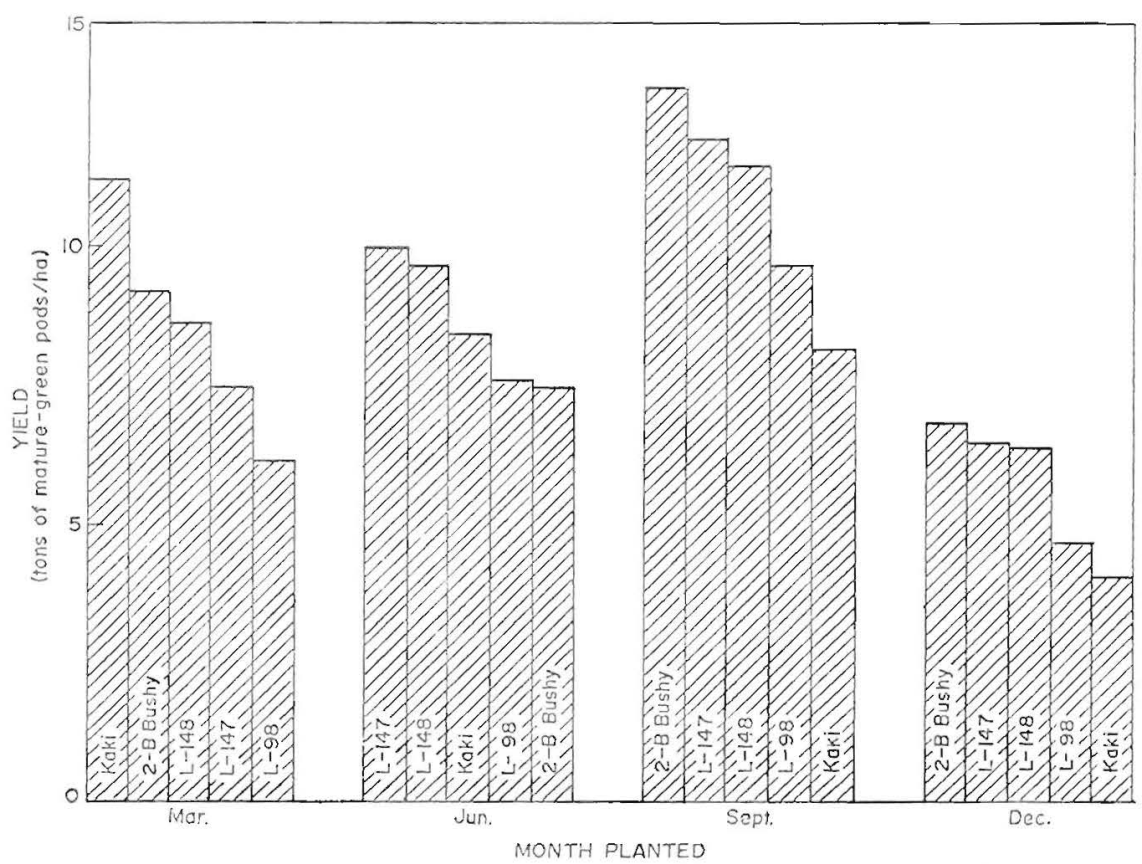

FrG. 1.-Effect of planting date on yields of five pigeon pea cultivars at Corozal.

TABLE 1.-Yields of five pigeon pea cultivars planted in September in two different ecological regions of Puerto Rico

\begin{tabular}{llc}
\hline \multirow{2}{*}{\multicolumn{1}{c}{ Cultivar }} & \multicolumn{2}{c}{ Yields (kg of mature-green pods/ha) } \\
\cline { 2 - 3 } & $\begin{array}{c}\text { Dry region } \\
\text { (Santa Isabel) }\end{array}$ & $\begin{array}{c}\text { Humid region } \\
\text { (Corozal) }\end{array}$ \\
\hline Line 147 (determinate) & $16,195^{\mathrm{al}}$ & $11,900^{\mathrm{a}}$ \\
2-B Bushy (determinate) & $15,000^{\mathrm{a}, \mathrm{b}}$ & $12,935^{\mathrm{a}}$ \\
Line 98 (determinate) & $13,880^{\mathrm{b}}$ & $9,720^{\mathrm{b}}$ \\
Line 148 (determinate) & $13,800^{\mathrm{b}}$ & $11,435^{\mathrm{a}}$ \\
Kaki (indeterminate) & $13,060^{\mathrm{b}}$ & $8,115^{\mathrm{b}}$ \\
\hline
\end{tabular}

${ }^{1}$ Means in columns followed by the same letters do not differ significantly at the $\mathrm{P}=$ 0.05 probability level (Duncan's multiple range test). 
highest yields when it was planted in March: 11,250 kg of mature-green pods/ha (fig. 1).

At Santa Isabel, 2-B-Bushy and line 147 were the highest, producing 15,000 and $16,195 \mathrm{~kg} / \mathrm{ha}$, respectively (table 1 ).

\section{Comparison between locations for the September planting}

On the average, yields of pigeon peas at Santa Isabel were about $25 \%$ higher than at the Corozal Substation (table 1). The indeterminate Kaki cultivar yielded $38 \%$ more, whereas 2 -B-Bushy yielded only $14 \%$ more at Santa Isabel than at Corozal. The higher yields obtained at Santa Isabel may be attributed to the higher sunlight intensity in the semi-arid region and, under these conditions, a lower incidence of rust disease caused by Uromyces dolicholi, Arth.

\section{EFFECT OF PRUNING}

Pruning significantly decreased yields in all pigeon pea cultivars at all pruning dates and locations. At Corozal, average yields from the September planting were 10,435 and $11,210 \mathrm{~kg} /$ ha for pruned and unpruned bushes, respectively. At Santa Isabel, mean yields for the September planting were 12,315 and $16,490 \mathrm{~kg} /$ ha for pruned and unpruned bushes, respectively. The cultivar $\times$ pruning action was not significant.

In the experiment on pruning heights at Corozal, severe pruning (cutting bushes back to heights of 30 or $60 \mathrm{~cm}$ after the first crop was harvested) sharply decreased yields of the second crop as shown in the following tabulation. This reduction in yield may be attributed to the short period of vegetative regrowth occurring before the bushes flowered again and, to a lesser extent, to loss of bushes due to stem rot disease caused by Phytophthora sp. and Botryodiplodia sp., which was more severe in the heavily pruned bushes.

Treatment

No pruning

Trimming about $8 \mathrm{~cm}$ from the branch tips

Pruning bushes to $60 \mathrm{~cm}$ above-ground

Pruning bushes to $30 \mathrm{~cm}$ above-ground
Yields ( $\mathrm{kg}$ of mature-green pods/ha)

$8,080^{84}$

$8,240^{\mathrm{a}}$

$4,400^{\mathrm{b}}$

$2,750^{c}$

${ }^{4}$ Means followed by the same letters do not differ significantly at the $\mathrm{P}=0.05$ probability level (Duncan's multiple range test).

\section{RESUMEN}

Se determinó el efecto de la época de siembra y de la poda en el rendimiento de cinco cultivares de gandul.

Las cultivares de crecimiento determinado (2-B-Bushy y las líneas 98, 147 y 148 desarrolladas por la Estación Experimental Agrícola) y la 
variedad Kaki, de crecimiento indeterminado, se sembraron en septiembre y diciembre de 1980 y en marzo y junio de 1981 en la Subestación de Corozal. Se realizó una siembra en septiembre en regadío cerca de Santa Isabel.

Todas las cultivares se podaron después de completarse la primera cosecha.

En Corozal, las variedades determinadas produjeron más cuando se sembraron en septiembre, siendo las cultivares 2-B-Bushy y las líneas 147 y 148 las más productivas, con un rendimiento medio de $12,090 \mathrm{~kg}$ de vainas verdes/ha. Los rendimientos más bajos se obtuvieron en la siembra más tardia, diciembre.

Los rendimientos más altos de la variedad indeterminada Kaki se obtuvieron en la siembra de marzo con una producción de $11,250 \mathrm{~kg}$ de vainas verdes/ha.

En Santa Isabel, las cultivares de rendimientos más altos fueron la 2-BBushy y la linea 147 , con una media de $15,600 \mathrm{~kg}$ de vainas verdes/ha.

La poda severa de los gandules después de completarse la primera cosecha redujo drásticamente los rendimientos de la cosecha subsiguiente, independientemente de las variedades, época de siembra y localización.

Los rendimientos en Santa Isabel fueron alrededor de 25\% más altos que en Corozal.

\section{LITERATURE CITED}

1. Abrams, R. and Juliá, F., 1973. Effect of planting time, plant population and row spacing on yield and other characteristics of pigeon peas, Cajanus cajan (L.) Millsp. J. Agric. Univ. P.R. 57 (4): 275-85.

2. Estación Experimental Agrícola, 1977. Conjunto Tecnológico para la Producción de Gandules: Su situación económica y sus perspectivas, Agric. Exp. Stn., Univ. P.R., Publ. 116.

3. Irizarry, H. and Rivera, E., 1983. Nutrient uptake and dry matter production by intensively managed pigeon pea grown on a Corozal clay, an Utisol, J. Agric. Univ. P.R. 67 (3): 188-96.

4. Olivencia, P., 1937. Breves datos sobre henificación de gandules, Rev. Agric. P.R. 28: 787-88.

5. Riollano, A., Pérez, A. and Ramos, C., 1962. Effect of planting date, variety and plant population on the flowering and yield of pigeon peas (Cajanus cajan (L)) J. Agric. Univ. P.R., 46 (2): 127-34.

6. Rivera, E., Silva, S. and Vicente-Chandler, J., 1983. Distribution on pigeon peas, cassava, coffee and grass roots in an Utisol, J. Agric. Univ. P.R. 67 (3): 278-85.

7. Soldevila, M. and Salas-Herrero, B., 1978. Utilization of pigeon pea (Cajanus cajan) by-products as feed for beef cattle, J. Agric. Univ. P.R. 62 (4) 424-27. 